Mineralogical Journal, Vol. 4, No. 1, pp. 12-29, Feb., 1963

\title{
RADIOACTIVE EQUILIBRIUM IN THE NINGYOTOGE URANIUM ORES, ESPECIALLY BETWEEN IONIUM AND URANIUM
}

TOHRU MURANO

Atomic Fuel Research Laboratory, Atomic Fuel Corporation

\section{ABStRACT}

The radioactive equilibrium states in the uranium ores of the Ningyotoge mine were investigated in relation to their ionium content and to their microscopic features.

An analytical method of $\mathrm{Io} / \mathrm{U}$ was examined and applied to the ores. The method is characterized by not being necessary to determine the chemical yield in the separation of thorium and by simplicity for obtaining the absolute value of $\mathrm{IO} / \mathrm{U}$. In order to investigate the states being different in phases of a specimen, variation of Io/Th-234 under chemical leaching was traced. Autoradiography and radioactivity measurements were also done.

The states of the radioactive equilibrium in the Ningyotoge ores are thought to be a results of the differentiation of thorium from uranium. This may occur by oxidation and chemical leaching and by crystallization of uranium minerals. The radiocolloid is explained as being a product of this differentiation. The radioactive nuclides included in the radiocolloid are ionium and its daughter products.

\section{Introduction}

States of the radioactive equilibrium of uranium ores have been studied for two purposes; one is to remove the disturbances in uranium radiometry due to the existence of the disequilibrium ${ }^{122}$, and the other to measure the disequilibrium state itself and to explain its geological meanings ${ }^{334536)}$. The present study was done for the 
same purpose as the latter on the states of the radioactive equilibrium in the uranium ores of the Ningyotoge mine.

The ore deposits of the Ningyotoge mine are the representative ones of uranium deposits of sedimentary type in Japan. Concerning the ore deposits, N. Katayama et al. discussed beta-counts par unit uranium content in relation to the occurrences of the ores in $1957^{4}$. I. Hayase reported and discussed the radioactive disequilibrium and the radiocolloid in 1959;. Radium of autunite from the ore deposits. was analyzed and discussed by $M$. Umemoto et al. in $1957^{\circ}$ and by $T$. Soma in $1957^{9}$. In these papers, the states of the radioactive equilibrium were considered mainly as a relationship between uranium and radium.

The states of the radioactive equilibrium are, in principle, determined by the ratios of uranium to its daughter products. Among these products, Io $(\mathrm{Th}-230)$ and $\mathrm{U}-234$ are supposed to affect the states during long time, because they have long half-lives and are situated in the upper positions of the uranium decay series. The disequilibrium between Io and its daughter products may disappear comparatively in short time, $10^{4}$ years. The radiocolloid was found in a altered pitchblende by $\mathrm{H}$. Yagoda in $1946^{10}$. It is also found widely in the Ningyotoge uranium deposits. The Ningyotoge ores. are classified into two kinds: unoxidized ores and oxidized ores. The oxidation has been thought to have a close relationship with these equilibrium phenomena. In this paper the author wishes to present an explanation of the relationships of Io to (1) the states of the radioactive equilibrium in the ores, especially the differences of the states between the unoxidized ore and the oxidized ore, and to (2) the radiocolloid.

\section{Experimental}

The radioactive nuclides of the uranium decay series are divided, for convenience, into four groups: U-group (U-238 U-234), Io(Th-230), Ra-group (Ra-226 $\sim \mathrm{Po}-214$ ), and $\mathrm{Pb}-$ group ( $\mathrm{Pb}-210 \sim \mathrm{Po}-210) . \mathrm{N}_{A} \lambda_{A}$ is 
abbreviated to $A^{*}$, where $N_{A}$ is number of atoms of nuclide $A$, and $\lambda_{A}$ is decay constant of nuclide $A$.

\section{Samples}

The uranium ore deposits of the Ningyotoge mine are formed in Neogene Tertiary lucustrine sediments, chiefly conglomerate and shale, lying horizontally on a granite base. The deposits of the Togo mine, which bounds the Ningyotoge mine on the south, belong to the same type. In the unoxidized zone, uranium occurs principally as ningyoite, $\mathrm{U}_{1-x} \mathrm{Ca}_{1-x} \mathrm{R} \mathrm{E}_{\cdot 2 . x}\left(\mathrm{PO}_{4}\right)_{2} 1 \sim 2 \mathrm{H}_{2} \mathrm{O}$, accompanied with pyrite and carbonaceous matter. The ningyoite is so fine in crystal size, less than $5 \mu$, that it is difficult to obtain pure samples by separation. Uraninite is also found in this zone in very small quantities. In the oxidized zone, the main uranium mineral is autunite. Beta-uranophane, uranophane, and carnotite are found. The pyrite has been oxidized to limonite. The autunite, $1 \sim 3 \mathrm{~mm}$ in size, crystallizes often on the surface of the limonite. The beta-uranophane is formed for the most part by replacing fossil woods and is often associated with autunite. Details of the mineralogy and the geology of the Ningyotoge ore deposits should be referred to other papers ${ }^{11) 12}$ (13)1415). The samples listed in Table 1 were investigated.

(1) Sample I, no. $1 \sim$ no. 6 , are the unoxidized ores: no. $1 \sim$ no. 4 were collected from the unoxidized zone of the Ningyotoge uranium deposits, and the other two sampled for comparison. No. 5 is representative specimen occurring in the Ogamo uranium ore deposits, which are characterized by coffinite ${ }^{26}$. No. 6 is a typical specimen of pitchblende collected by Dr. M. Sato from the MiVida mine, Utah, U.S. A., and is principally composed of uraninite with minor amount of calcite. The radioactive equilibrium is supposed to be established in it, considering its unweathered features and the geological age of the MiVida deposits.

(2) Sample II, no. $7 \sim$ no. 14 , were collected from the oxidized 
Table 1. List of the samples investigated.

\begin{tabular}{|c|c|c|c|}
\hline Sample & Rock Type & $\begin{array}{l}\text { Uranium } \\
\text { Mineral }\end{array}$ & Locality \\
\hline $\begin{array}{l}\text { no. } 1 \\
\text { no. } 2 \\
\text { Io. } 3 \\
\text { no. } 4 \\
\text { no. } 5 \\
\text { no. } 6\end{array}$ & $\begin{array}{l}\text { Conglomerate } \\
\text { Conglomerate } \\
\text { Conglomerate } \\
\text { Tuff-breccia } \\
\text { Quartz vein } \\
\text { Pitchblende }\end{array}$ & $\begin{array}{l}\text { Ningyoite } \\
\text { Ningyoite } \\
\text { Ningyoite } \\
\text { Ningyoite } \\
\text { Coffinite } \\
\text { Uraninite }\end{array}$ & $\begin{array}{l}\text { Toge area, Ningyotoge Mine } \\
\text { Toge area, Ningyotoge Mine } \\
\text { Toge area, Ningyotoge Mine } \\
\text { Asabatake area, Togo Mine } \\
\text { Ogame Mine } \\
\text { MiVida Mine, Utah, U.S.A. }\end{array}$ \\
\hline $\begin{array}{l}\text { no. } 7 \\
\text { no. } 8 \\
\text { no. } 9 \\
\text { II } \\
\text { no. } 10 \\
\text { no. } 11 \\
\text { no. } 12 \\
\text { no. } 13 \\
\text { no. } 14\end{array}$ & $\begin{array}{l}\text { Conglomerate } \\
\text { Conglomerate } \\
\text { Conglomerate } \\
\text { Conglomerate } \\
\text { Conglomerate } \\
\text { Conglomerate } \\
\text { Conglomerate } \\
\text { Conglomerate }\end{array}$ & $\begin{array}{l}\text { Autunite } \\
\text { Autunite } \\
\text { Autunite } \\
\text { Autunite } \\
\text { Autunite } \\
\text { Autunite } \\
\text { Autunite } \\
\text { Autunite }\end{array}$ & $\begin{array}{l}\text { Toge area, Ningyotoge Mine } \\
\text { Toge area, Ningyotoge Mine } \\
\text { Toge area, Ningyotoge Mine } \\
\text { Toge area, Ningyotoge Mine } \\
\text { Toge area, Ningyotoge Mine } \\
\text { Toge area, Ningyotoge Mine } \\
\text { Yotsugi area, Ningyotoge Mine } \\
\text { Yotsugi area, Ningyotoge Mine }\end{array}$ \\
\hline $\begin{array}{l}\text { no. } 15 \\
\text { III } \\
\text { no. } 16\end{array}$ & $\begin{array}{l}\text { Fossil wood } \\
\text { replaced by } \mathrm{U} \\
\text { Same as no. } 15\end{array}$ & $\begin{array}{l}\text { Beta- } \\
\text { uranophane } \\
\text { Autunite }\end{array}$ & $\begin{array}{l}\text { Katamo area, Togo Mine } \\
\text { Katamo area, Togo Mine }\end{array}$ \\
\hline
\end{tabular}

zone of the Ningyotoge deposits: no. $7 \sim$ no. 9 are crude ores, while, no. $10 \sim$ no. 14 are samples of autunite separated under binocular microscope.

(3) Sample III, no. 15 and no. 16, are the oxidized ores collected from the Togo mine. No. 15 is beta-uranophane replacing fossil wood and no. 16 is autunite found on the surface of the sample no. 15.

\section{Radioactivity measurements}

The equilibrium states within U-group*, within Ra-group, and between Ra-group and $\mathrm{Pb}$-group are established in short time. In natural uranium ores these equilibrium states are generally found, and are used for uranium radiometry ${ }^{122}$. In order to check these

* In this case U-234 is not included in U-group. 
states in the samples beta and gamma countings were done. The counters used were a G-M tube and a gamma-ray spectrometer accompanied with a well type thallium activated $\mathrm{NaI}$ crystal, $13 / 4^{\prime \prime}$ dia. $2^{\prime \prime}$ high, and a twenty-channel pulse height analyzer. Then were calculated three ratios: beta-counts per unit uranium content (beta/U), area of $610 \mathrm{kev}$-gamma peak to uranium content $(610 \mathrm{kev} / \mathrm{U})$, and height of $80 \mathrm{kev}$.gamma peak to uranium content $(80 \mathrm{kev} / \mathrm{U})$. The peak of $80 \mathrm{kev}$-gamma is composed of $93 \mathrm{kev}$ and $64 \mathrm{kev}$, gammas of $\mathrm{Th}-234$ and $74 \mathrm{kev}, \mathrm{KX}$-ray of $\mathrm{Pb}^{17}$. The peak of $610 \mathrm{kev}-$ gamma is due to $\mathrm{Bi}-214$.

The results of the measurements are shown in Table 2. Linear

Table 2. Results of the radioactive measurements of the uranium ores.

\begin{tabular}{l|c|c|c}
\hline Sample & $80 \mathrm{kev} / \mathrm{U}$ & $610 \mathrm{kev} / \mathrm{U}$ & Beta/U \\
\hline no. 1 & 2032 & 552 & 3028 \\
no. 2 & 5650 & 1630 & 6010 \\
no. 3 & 4476 & 1365 & 5309 \\
no. 4 & 1765 & 392 & 2795 \\
no. 5 & 1505 & 359 & 2428 \\
no. 7 & 1387 & 249 & 2334 \\
no. 8 & 2211 & 507 & 3344 \\
no. 17 & 1569 & 357 & 2532 \\
no. 18 & 1539 & 310 & 2499 \\
\hline
\end{tabular}

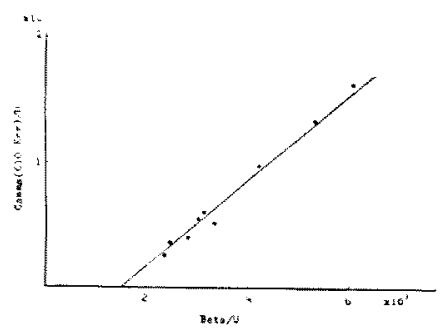

Fig. 1. Beta/U vs. 610 kev-gamma/U of the ura. nium ores.

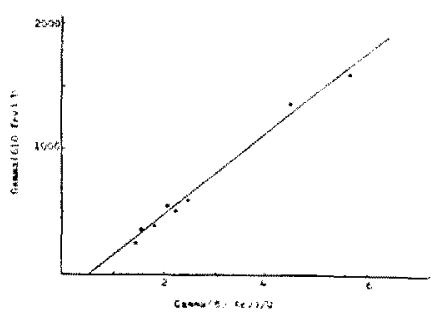

Fig. 2. $80 \mathrm{kev}$-gamma/U vs. $610 \mathrm{kev}$-gamma/U of the urańium ores. 
relationships are found among these three ratios; between $610 \mathrm{kev} / \mathrm{U}$ and beta/U; between $610 \mathrm{kev} / \mathrm{U}$ and $80 \mathrm{kev} / \mathrm{U}$. . Fig. 1 and 2 illustrate them. These results indicate that (1) beta-counts due to U-group are nearly constant, (2) beta-counts due to Ra-group and Pb-group nearly proportional to $610 \mathrm{kev}$-gamma or Ra-group content, and (3) gamma-counts due to U-group nearly constant too. Consequently, it may be said that the equilibrium states above stated are recognized in these samples.

In order to investigate the microscopic distribution of alphaemitters in the ores, microautoradiographs were taken with alpha sensitive nuclear emulsion (Fuji contact type autoradiographic plate ${ }^{18119}$. Alpha-tracks were observed corresponding to limonite and radiocolloid besides the uranium minerals. Sometimes biotite contains alpha-emitters.

III. Analysis for $U-234^{*} / U-238^{*}$

Uranium was separated from the sample by solvent extraction with tributyl phosphate, and by anion exchange with Dowex 1-X8. The alpha-ray spectrum of the separated uranium was obtained by a gridded ionization chamber accompanied with a twenty-channel pulse height analyzer. This gridded ionization chamber was described in detail by $T$. Doke et al. in $1960^{20)}$.

Two representative samples, no. 1 (unoxidized ore) and no. 7 (oxidized ore), were analyzed in this way. The alpha-ray spectra for no. 1 is shown by Fig. 3 , the

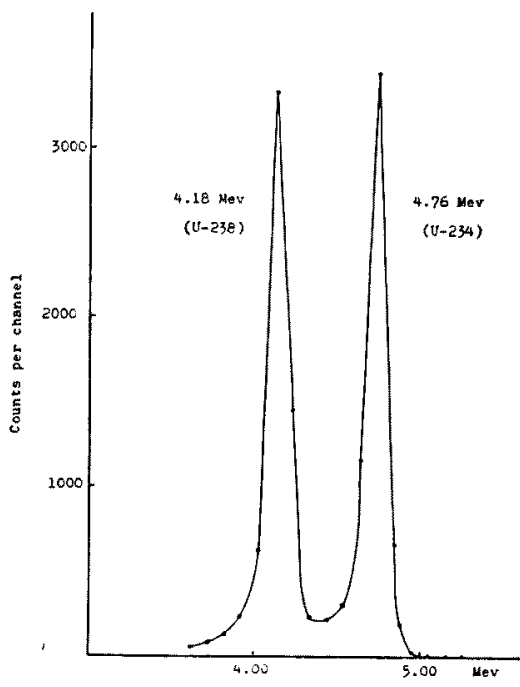

Fig. 3. Alpha-ray spectra of uranium separated from the unoxidized uranium ores. 
spectra for no. 7 are almost the same. In both spectra, $4.18 \mathrm{Mev}$-alpha of U-238 and $4.76 \mathrm{Mev}$-alpha of U-234 are observed distinctly. Difference in the areas of these two peaks is about $3 \%$ for both samples, which is not significant in consideration of the experimental error, about $5 \%$. Thus the disequilibrium is not found between U234 and $\mathrm{U}-238$.

\section{Radiocolloid concentration}

The concentration of the radiocolloid in the samples was measured as following. Pulverized sample, about $2 \mathrm{~g}$, was packed in a glass tube, $22 \mathrm{~mm}$ in diameter, about $15 \mathrm{~mm}$ long, without use of binding material. The tube packed with the sample was placed in contact with the autoradiographic plate for about 100 hours. The plate was developed, fixed and then examined under a nuclear track research microscope. The radiocolloids were recorded as stars of alpha tracks. Total number of the stars $(\mathrm{N})$ was counted. The concentration of the radiocolloid may be expressed as $N / U / A$, where $\mathrm{U}$ is uranium content $(\%), \mathrm{A}$ is area $\left(\mathrm{cm}^{2}\right)$ of the glass tube. The results obtained are shown in Table 3 .

\section{Analysis for $I o^{*} / U-238^{*}$}

(1) Principle The thorium isotopes in uranium ores are Io, Th-234, Th-231 and Th-227, which are expressed in Fig. 4 with dotted lines. Among these isotopes, Io and Th-234 belong to the uranium decay series, and the others to the actinium series. The radioactivities of the separated thorium are derived from Io and

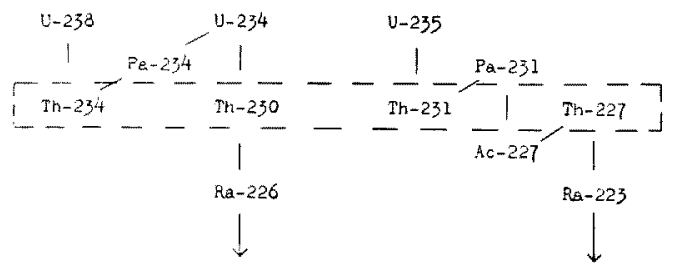

Fig. 4. Upper parts of the uranium and actinium decay series. 
Th-234, if the radioactivities due to the other isotopes are neglected. The $\mathrm{Th}-234$ will be in equilibrium with $\mathrm{Pa}-234$ in about 10 minutes. Thus the separated thorium contains Io as an alpha-emitter, and $\mathrm{Th}-234$ and $\mathrm{Pa}-234$ as beta-emitters. When $\mathrm{Th}_{\beta}$ are the beta-counts of the separated thorium and $\mathrm{Th}_{\alpha}$ its alpha-counts, $\mathrm{Th}_{a} / \mathrm{Th}_{\beta}$ is proportional to $\mathrm{Io}^{*} / \mathrm{Th}-234^{*}$ or $\mathrm{Io}^{*} / \mathrm{U}-238^{*}$, if $\mathrm{U}-238$ is in equilibrium with Th-234. A thin film of uranium, in which $\mathrm{U}-238$ is in equilibrium with U-234 and Th-234 is formed on a Pt-foil and is counted to obtain the alpha-counts $\left(U_{c}\right)$ and the beta-counts $\left(U_{\beta}\right)$ under the same condition as the countings of the thorium. Io*/U-238* may be expressed as follows:

$$
\mathrm{IO}^{*} / \mathrm{U}-238^{*}=2 \cdot \mathrm{Th}_{\alpha} / \mathrm{Th}_{\beta} \cdot \mathrm{U}_{\beta} \mathrm{U}_{\alpha} .
$$

Correction of $\mathrm{Th}_{\alpha} / \mathrm{Th}_{\beta}$ for the disintegration of $\mathrm{Th}-234$ and $\mathrm{Th}-227$ is necessary. But there is no need to consider the correction for Th-231, because $\mathrm{Th}-231$ is thought to be in equilibrium with U-238 both in the sample and in the uranium foil. The error due to the contamination of $\mathrm{Th}-232,1 \%$ for uranium, is about $0.6 \%$.

(2) Procedure

(a) Separation Thorium was separated by coprecipitation with $\operatorname{Pr}$ carrier ${ }^{21)}$, and by a cation exchange resin ${ }^{22)}$. There is no need for quantitative separation in this analytical method.

Pulverized sample, $1 \sim 3 \mathrm{~g}$, was dissolved with aqua regia, evaporated and filtrated to remove the insoluble material. The filtrate was added with $\mathrm{Bi}$ and $\mathrm{Pb}$ carriers, each of $20 \mathrm{mg}$, then saturated with $\mathrm{H}_{2} \mathrm{~S}$ and filtrated to remove $\mathrm{Pb}, \mathrm{Bi}, \mathrm{Po}$, and other heavy metals. The filtrate was boiled to drive out $\mathrm{H}_{2} \mathrm{~S}$ gas and diluted to $50 \mathrm{ml}$ with $0.5 \mathrm{M}$ oxalic acid. Th in the solution was coprecipitated with $\operatorname{Pr}$ carrier, $20 \mathrm{mg}$, under boiling. The precipitate was dissolved in $10 \mathrm{ml}$ of $2 \mathrm{~N} \mathrm{HNO}_{3}$, added with distilled water to $20 \mathrm{ml}$. Th was separated from the Pr carrier and others by cation exchange. The column used was $0.6 \mathrm{~mm}$ in diameter and $15 \mathrm{~cm}$ long. As cation exchange resin, Dowex 50-X4, 50 100 mesh, $2 \mathrm{ml}$, was used. After 
absorption, the resin was washed with $20 \mathrm{ml}$ of $3 \mathrm{~N} \mathrm{HCl}$ and $10 \mathrm{ml}$ of distilled water, then, Th was eluted with $0.5 \mathrm{M}$ oxalic acid.

Completeness of the separation and contamination of Th-232 were checked by beta counting and gamma and alpha spectrometries.

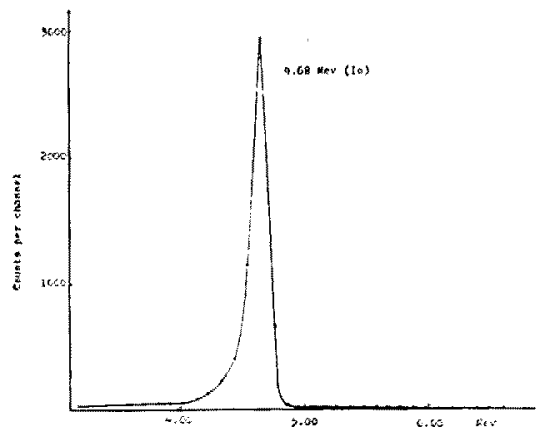

Fig. 5. Alpha-ray spectrum of thorium separated from the unoxidized ores.

Decrease of the beta-counts. due to the half-life (24.1 days) of Te-234, (93 kev-gamma) was observed. The alpha-ray spectrum of the separated thorium is shown in Fig. 5, in which $4.68 \mathrm{Mev}$-alpha of Io is observed, and any contaimination of other alpha-emitters is not found. The calibration. of energy in the spectrometry was made with $5.15 \mathrm{Mev}$-alpha. of $\mathrm{Pu}-239$.

(b) Sample preparation and counting. On a Pt-foil, $0.03 \mathrm{~mm}$ in thickness, and 25 by $25 \mathrm{~mm}$ square, $0.3 \mathrm{ml}$ of the eluted solution was dropped from the column directly. It was evaporated quietly to dryness by an infrared lamp, heated to about $180^{\circ} \mathrm{C}$ by taking the lamp near the $\mathrm{Pt}$-foil to sublimate the oxalic acid, then heated to red in flame. The sample thus prepared was counted for its alpha and beta activities. The counter used was a two pi proportional counter (Type PC-3A, Nuclear Measurement Co.) with PR-gas, 95\% of argon and $5 \%$ of methane.

The standard deviation for seven values obtained from repeated. analyses for one sample was $2.75 \%$.

(3) Results

(a) Sample no. 6 (MiVida pitchblende) was analyzed repeatedly, for $10^{*} / \mathrm{U}-238^{*}$ were obtained two values: 1.02 and 0.98 . It may be proved that the equilibrium of Io to $\mathrm{U}-238$ is established in this specimen. This result has been expected beforehand as already 
Table 3. Experimental results for $10^{*} / \mathrm{U}-238^{*}$ analyses and for radiocolloid concentration measurements. (Analysts for $U: S$. Watanabe and S. Motoyama, Atomic Fuel Research Institute)

\begin{tabular}{|c|c|c|c|c|c|}
\hline \multicolumn{2}{|c|}{ Sample } & $\mathrm{U}(\%)$ & $\mathrm{Io}^{*} / \mathrm{U}-238^{*}$ & Radiocolloid & Beta/U \\
\hline \multirow{6}{*}{ I } & no. 1 & 0.98 & 1.14 & 33 & 3028 \\
\hline & no. 2 & 0.20 & 1.75 & 334 & 6010 \\
\hline & no. 3 & 0.17 & 1. 43 & 179 & 5309 \\
\hline & no. 4 & 0.31 & 1.03 & 1 & 2795 \\
\hline & no. 5 & 0.99 & 1.11 & 49 & 2428 \\
\hline & กo. 6 & 50.5 & 1.00 & 0 & - \\
\hline \multirow{8}{*}{ II } & no. 7 & 2.04 & 1.00 & 1 & 2334 \\
\hline & no. 8 & 0.09 & 1.25 & 23 & 3344 \\
\hline & no. 9 & 0.39 & 1.21 & 30 & 3108 \\
\hline & no. 10 & - & 0.82 & 0 & - \\
\hline & no. 11 & - & 0.62 & 0 & - \\
\hline & no. 12 & - & 0.70 & 0 & - \\
\hline & no. 13 & - & 0.71 & 0 & - \\
\hline & no. 14 & - & 0.72 & 0 & - \\
\hline \multirow{2}{*}{ III } & no. 15 & - & 1.06 & 0 & - \\
\hline & no. 16 & - & 0.72 & 0 & - \\
\hline
\end{tabular}

stated.

Analytical results of the samples listed in Table 1 are shown in Table 3.

(b) Relationship between beta-counts/U and Io*/U-238* is expressed in Fig. 6. It indicates a trend that beta-counts are increased with Io content.

(c) Relationship of $10^{*} / \mathrm{U}-238^{*}$ to the radiocolloid concentration in the unoxidized ores is illustrated by Fig. 7. When $10^{*} / \mathrm{U}-238^{*}$ is less than 1.00, radiocolloid is not found. But the radiocolloid concentration increases with increasing Io, when Io/U-238* is more than 1.00. A probable explanation of these relationships is that Io is in equilibrium with $\mathrm{U}-238$ in the uranium mineral, ningyoite, and the excess amount of $I 0$ is included in the radiocolloid free from 


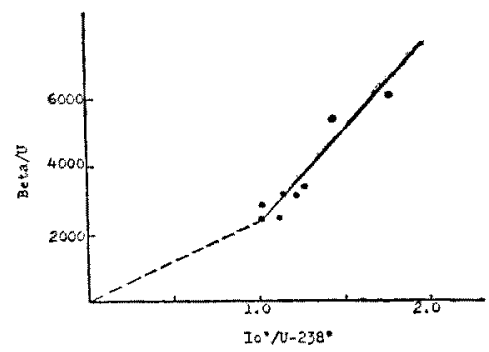

Fig. 6. Beta/U vs. Io*/U-238* in the uranium ores.

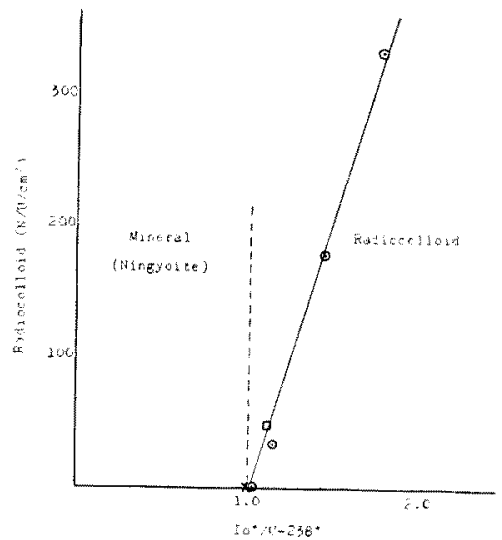

Fig. 7. Relationship between Io and the radiocolloid in the oxidized ores.

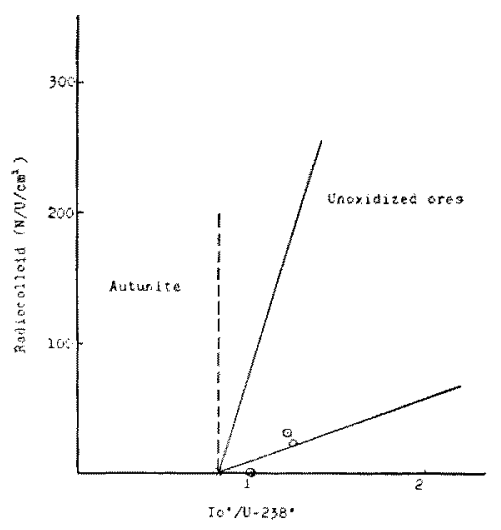

Fig. 8. Relationship between Io and the radiocolloid in the unoxidized ores.

uranium. Sample no. 5 plotted in Fig. 7 with symbol $\square$ seems to have the same relationships as the others. This is also reasonable, because the coffinite is a primary mineral of the Ogamo ore deposits and expected to have Io in equilibrium with U-238.

(d) In the autunite samples $10 * / \mathrm{U}-238 *$ is lesser than 1.00 as shown in Table 3. This seems to correspond to the fact that the autunite is a secondary mineral. But Io in the oxidized ores, as a whole, is in excess for the equilibrium state. Fig. 8 illustrates the relationships between $10 * / \mathrm{U}-238^{*}$ and the radiocollid concentration in the oxidized ores. Even if $10^{*} / \mathrm{U}-238^{*}$ for the autunite is assumed to be 0.82 , the maximum value for the autunite samples, the radiocolloid concentration is too small to explain the lo content. Limonite is the only phase containing radioactive nuclides except the autunite and the radiocolloid. Thus, it may be said that to in 
the limonite is in excess for the equilibrium state.

(e) Table 3 shows that the ratio, Io*/U-238*, of sample no. 16 is less than 1.00, while that of sample no. 15 is nearly 1.00. These results explain that the autunite is the secondary mineral after beta-uranophane.

\section{Variation of $10^{*} / T h-234^{*}$ under leaching}

A method of investigation by means of chemical leaching is available for studing the states of the radioactive equilibrium of a specimen in which these states are different in phases.

(1) Principle. Two models are illustrated in Fig. 9, where (A) is a case in which $U$ and Io are contained in one phase, while (B) is a case in which

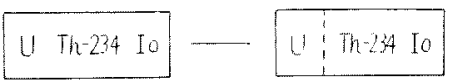
(A) they are contained separately into two phases which are different in chemical properties. In both cases, it is assumed that $\mathrm{U}-238$ is in equilibrium with $\mathrm{Th}-234$, and Th-232 is not contained or

negligible. When a sample is leached in the case of (A), Io/Th-234 is $k \in \mathrm{pt}$ to be constant throughout leaching, although the ratio of $\mathrm{U}$ to these Th isotopes may vary. While in the case of (B), Io/Th234 possibly varies in the course of leaching. If the behaviors of these two phases under chemical leaching are known, it may become clear which phase contains Io or $U$ by tracing the variation of $10^{*} / \mathrm{Th}-235^{*}$ under leaching. On the contrary, if the phase which contains lo or $\mathrm{U}$ is known, the differences in the behaviors of these phases under leaching may be found in the same way.

This method seems to be applicable to and useful for studing the Ningyotoge ores whose radiocolloid and ningyoite are too fine to be separated from each other. 
(2) Procedure. Sample, $10 \mathrm{~g}$ of the pulverized ore, was weighed into a glass column, $10 \mathrm{~mm}$ in diameter and $20 \mathrm{~mm}$ long, accompanied with a glass filter and a cock like that used in ion exchange. At first, distilled water, about $10 \mathrm{ml}$, was pushed into the column from its bottom, so that the bubbles in the column were removed. Then the sample was leached with $10 \mathrm{ml}$ of $6 \mathrm{~N} \mathrm{HCl}$ allowed to flow through the column at a rate of about $2 \mathrm{ml}$ per minute. Thus the filtrate $F_{1}$ was obtained. Next the sample was leached with another $10 \mathrm{ml}$ of $6 \mathrm{~N} \mathrm{HCl}$ and the filtrate $\mathrm{F}_{2}$ was obtained in the same way. Finally the sample was carried from the column to a flask, added with $20 \mathrm{ml}$ of aqua regia, and evaporated. The insoluble material was removed by dillution and filtration, and the filtrate $F_{3}$ was obtained. These three filtrates, $F_{1}, F_{2}$ and $F_{3}$, were analyzed for Io*/Th-234* by the same method as that for $10^{*} / \mathrm{U}-238^{*}$. The same experiments were done with $6 \mathrm{~N} \mathrm{H}_{2} \mathrm{SO}_{4}$ instead of $6 \mathrm{~N} \mathrm{HCl}$.

(3) Results. The method was applied to the samples, no. 2 and no. 7. Sample no. 2 is characterized with ningyoite and much radiocolloid, no. 7 is characterized with autunite and radioactive limonite. The radiocolloid concentration is very small for no. 7 as shown in Table 3. The experimental results are presented in Fig. 10. It is indicated that $\mathrm{Io}^{*} / \mathrm{Th}-234^{*}$ is not constant for both the samples. Consequently each sample has two phases which are different in $10^{*} / \mathrm{U}-238^{*}$ from each other.

(a) Sample no. 2 (unoxidized ore) In Fig. 10, it is indicated that the phase of high $10^{*} / \mathrm{U}-238^{*}$ is more leachable than the other phase of low $10^{*} / \mathrm{U}-238^{*}$ Accordingly it may be thought that the high $10^{*} / \mathrm{U}-238^{*}$ phase corresponds to the radiocolloid and the other phase corresponds to ningyoite.

(b) Sample no. 7 (oxidized ore) In the case of no. 7 , a reverse result is found in Fig. 10; the phase of low $\mathrm{Io}^{*} / \mathrm{U}-238^{*}$ is more leachable than the other. And it may be said that autunite corresponds to the phase which is low in the ratio and more leachable, and limonite corresponds to the other phase. 


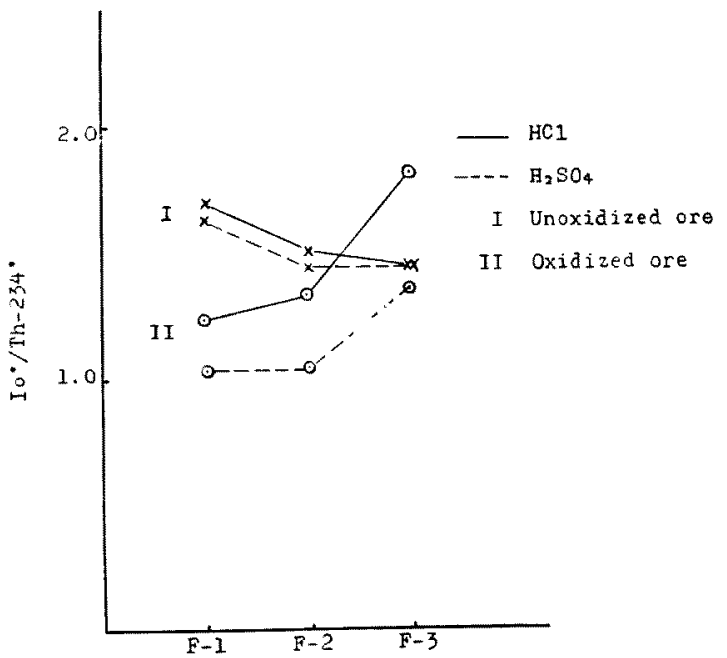

Fig. 10. Variation of Io*/Th234* by chemical leachings.

\section{Discussions and conclusions}

(1) The equilibrium between U-238 and U-234 has been assumed to be established without measurement. Isabaev et al. reported that U-234*/U-238* fluctuated in some secondary uranium minerals and it arrived the maximum value of about $3^{23}$. The results of the measurements of this ratio for two representative samples of the Ningyotoge ores indicate the establishment of the equilibrium. The conspicuous disequilibrium between these nuclides does not seem to exist in other samples. But it may rather be a future problem to measure the ratio more accurately and to investigate its geological and geochemical meanings in wider area including the Ningyotoge mine.

(2) An analitical method for $10 * / \mathrm{U}-238^{*}$ was examined and applied to the Ningyotoge ores. The method is based on the determination of isotopic ratio, Io/Th-234, and there is no need to determine the chemical yield in the separation of thorium. The absolute value of $10^{*} / \mathrm{U}-238^{*}$ is easily obtained by the use of uranium as 
the standard. Analytical error can be limited within 5\%.

As an application of this analytical method, was examined an experimental method by means of tracing the variation of $10^{*} / \mathrm{Th}$ $234^{*}$ under chemical leaching. This was proved to be useful to investigate the states of the equilibrium which are different in phases in one specimen.

(3) The radio of beta-counts to uranium content, which depends on U-group, Ra-group and $\mathrm{Pb}$-group, was turned out to vary with close relation to the Io content. It may be said that the Io content, in fact, affects considerably the states of the equilibrium between $\mathrm{U}-238$ and its daughter products below Io. But Ra-226 and $\mathrm{Pb}-210$ must be analyzed, at least, in order to discuss these states in detail.

According to the autoradiographic studies of the ores, the radioactive nuclides are contained not in uniform distribution but in microscopic units, in uranium minerals and radiocolloid. The states of the equilibrium, therefore, exist corresponding to such units.

In the unoxidized ores, Io is contained in excess for the equilibrium state, as a whole. This may be interpreted that Io in ningyoite is in equilibrium with $U$ but Io in excess is contained in the radiocolloid free from $U$.

In the oxidized ores, Io is also contained in excess for the equilibrium state as a whole. In this cases, Io in autunite is deficient for the equilibrium state to $U$, but Io in limonite is in excess for it.

The processes, which have caused these states, may be described as follows:

Th (Io)
Ningyoite $\rightarrow$ Radiocolloid + Uranyl solution
Uraniferous-. Uraniferous + Autunite
limonite $\quad$ limonite with
$\quad$ lo in excess

It is known that differenciation of $U$ from $T h$ generally occurs by oxidation and chemical leaching. There is no doubt about 
that the Ningyotoge uranium deposits have suffered from oxidation and chemical leaching. Process (a) shows that ningyoite has suffered from such reactions, and $U$ has been separated from Io and removed in uranyl solution, while lo left as radiocolloid. Process (b) ; in the oxidized zone, it is supposed that $U$ was fixed as uraniferous limonite at first, and then crystallized as autunite. The separation of $\mathrm{Th}$ from $\mathrm{U}$ has occurred during the crystallization.

Consequently, the states of the radioactive equilibrium in the Ningyotoge uranium ores are explained to be a result of the differentiation of uranium from thorium. On the contrary, these states are represent the various features of this differentiation.

(4) The radiocolloid was thought by $H$. Yagoda to be Ra-sulphate coprecipitated with $\mathrm{Pb}$-sulphate from the facts that the specific activity of the radiocolloid was extremely high and lead was detected at the very points where the radiocolloids were found. Since then it has been thought that the radioactive nuclides in the radiocolloid are radium and its daughter products.

In this work, it was proved that they are ionium and its daughter products, in which radium is included.

\section{Acknowledgements}

The author wishes to express his sincere thanks to Professor T. Watanabe, Geological Institute, University of Tokyo, and to Professor N. Katayama, College of General Education, University of Tokyo for their constant guidance and encouragement throughout this work. His thanks are also due to Assistant Professor I. Hayase, Geological and Mineralogical Institute, University of Kyoto, for his valuable criticism.

This work was carried out in the Atomic Fuel Research Institute, Atomic Fuel Corporation. Dr. M. Sato, Messr. F. Togo, T. Kawamura and M. Maruyama, and Drs. K. Kubo, T. Mito and T. Murase 
of the Corporation offered every facility for this work. He is indebted to Messrs. N. Shibata and K. Watanabe of the Japan Atomic Energy Research Institute, and Drs. F. Yamazaki and T. Hamada of the Institute of Physical and Chemical Research for their help and advice in performing measurements of radioactivity. $\mathrm{He}$ is also indebted to Assistant Professor T. Doke, St. Paul's University, who performed the alpha-ray spectrometric analyses.

\section{REFERENCES}

1) Eichholz, G. G., J.W. Hilborn and C. Mahon: Can. Jour. of Phys., 31, 613 (1953).

2) Damon, P.E. and H.W. Feely: U.S. Atomic Energy Comm., RME-3153 (1957).

3) Rosholt, J.N.: Peaceful Uses of Atomic Energy, Proc. Second Intern. Conf., 2, 230 (1958).

4) Katayama, N. and Y. Sato: Sci. Papers College of General Education, Univ. Tokyo, 7, 131 (1957).

5) Grace, J.D. and T.E. Bates: Geochim. et Cosmochim. Acta, 17, 226 (1959).

6) Facchini, U., M. Forte, A. Malvicini and T. Rossi: Nucleonics, 14, no. 9. 126 (1956).

7) Hayase, I.: Mem. Coll. Sci. Univ. Kyoto Ser. B26, 153 (1959).

8) Umemoto, H. and M. Sakanoue: Jour. Chem. Soc. Japan, 79, 27 (1958) (in Japanese).

9) Soma, T.: Jour. Miner. Soc. Japan, 3, 214 (1957) (in Japanese)

10) Yagoda, H.: Am. Miner. 31, 462 (1946).

11) Katayama, N. . Peaceful Uses of Atomic Energy, Proc. Second Intern. Conf., 2, 402 (1958).

12) Kubo, K. and T. Murano: Proceedings of the Second Symposium of Atomic Energy, B-67 (1958) (in Japanese).

13) Sato, M.: Peaceful Uses of Atomic Energy, Proc. Second Intern. Conf., 2, $110(1958)$.

14) Muto, T., R. Meyrowitz, A.M. Pommer and T. Murano: Am. Miner, 44, 633 (1959).

15) Muto, T. Miner. Jour., 3, 195 (1961).

16) Hamachi, T., Y. Sekine and S. Ishiwara: Bull. Geol. Survey of Japan, $10: 3$ (1959) (in Japanese).

17) Crouthamel, C.E.: Applied Gamma.ray Spectrometry, Pergamon Press (1960). 
18) Yagoda, H.: Radioactive Measurements with Nuclear Emulsions, John Wiley (1949).

19) Hayase, I.: Jour. Geol. Soc. Japan, 58, 33 (1952).

20) Doke, T., M. Tsukuda and I. Ogawa: Jour. of Applied Phys. Japan, 29, 573 (1960) (in Japanese).

21) Rosholt, J.N.: Anal. Chem., 29, 1398 (1957).

22) Barnes, J. W., E. J. Lang and H. A. Potratz: U. S. Atomic Energy Comm., LA-1845.

23) Isabaev, E. A., E.P. Usatov and V. V. Cherdyntsev: Radiokhimiya, 2, $94(1960)$.

Manuscript received May 20, 1962. 